\title{
Unfolding Layers of Labour: a Cross- Generational Account of Kinaesthetic Skills
}

Angela Costi, poet, freelance community writer and public servant

\begin{abstract}
Documenting migrant women's work through arts practice and community-engaged projects is a way of embedding their contribution to the history of working-class Australia. Through an analysis of Ancient Greek women's practice, migrant women's contribution to Australian labour, and poetic narrative incorporating oral history, this article highlights the kinaesthetic skills of the writer's Cypriot-Greek mother and grandmother. These skills are placed in the context of a market-driven system designed to turn skills into product and preference quantity over quality. The labour associated with making embroidery and garments is revisited through the writer's poetry and social justice lens. Two poems, Kinaesthetic Grace and Making Lace, which are informed by the labour and skills of the writer's mother and grandmother, are reinvented through an artistic collaboration with musicians and a filmmaker. The labour associated with this collaboration is unpacked as it resonates with the work of migrant women.
\end{abstract}

\section{Keywords}

Migrant woman, migrant worker, migrant labour, migrant working-class, factory work, kinaesthetic skills, arts practice, community-engaged practice, working-class poetry

\section{Kinaesthetic Grace (part 1)}

This woman talks to me with her hands

she always has, since birth

I have failed to grasp them.

I have followed the voices and text

I've found outside the home,

words on pages in whatever language, discipline or culture

bound by libraries,

left this woman to create her own story

with soil and seeds, flour and salt,

a cloth, a needle, a pot, an oven...

her fingers are an alphabet

I had no patience for. ${ }^{1}$

\section{Poetic memoir}

My mother, Eleni, is 74 years old and she still talks to me with her hands. They enter air as pen and paper remaking the book for her memories to turn story. Now that I have outgrown teenage

\footnotetext{
${ }^{1}$ The first section of a poem, Kinaesthetic Grace, by Angela Costi. This poem along with Making Lace will be interweaved throughout this article.
} 
drive and have teenage children of my own, I sit still enough to see how her hands are the subtext to all of her stories. They are labourer's hands with ditches and trenches to mark stories of struggle with work. They are traveller's hands with dunes and ridges to unpack stories of challenge with culture. They are miracle maker's hands with rivers and gardens to host stories of conquest with tools. They speak of resilience despite the voice disclosing the wheeze of tired lungs.

In recent months, perhaps due to increase anxiety with COVID19 restrictions and being unable to visit her sister, go to Church nor hug her grandchildren, Eleni's hands are quiet. We sip our briki coffee or $t s a i^{2}$ with milk and honey and work out ways to live without touch.

\section{Oral story and context}

There's her default story; the one that makes her hands twitch when she's in the thick of telling. At one point, they become the needle of the sewing machine as she recounts how she began working at the clothing factory when she was $13 .^{3}$

I wanted to go to training school to become a nurse, but my mother said there was no money to send me, my father said no daughter of his was going to wipe the shit off men's arses. My English was very broken back then. My oldest sister lied about my age so I could work with her at the factory.

The machines never stopped making noise and sewed up women's hands by mistake. I was the lucky one to escape the drill of the needle and thread. After seven years, the boss said my hems and sleeves were the best but I wasn't quick enough. He gave me another job inspecting the quality of the clothes. My daily quota was 2,500 garments. I had to scan the clothes for flaws and staple labels on them at the same time. I got $\$ 10$ a day if I met the quota. If I did more, I got a bonus.

This was in the 1960s and 1970s when working conditions in Australian factories were not monitored and regulated as much as they appear to be now. Certain documented, communityengaged arts practices ${ }^{4}$ have brought to the fore the contribution of migrant female factory workers to the Australian workforce:

Australia has the largest overseas-born workforce outside of Israel. At least half of the population of Perth and Melbourne are products of post-1945 settlement. Of all women working in Australian industry, 60\% are born overseas (Duke, Lyssiotis, Mehes 1986, p. 12).

Eleni vividly recalls both the bullying work expectations of her boss and the sense of pride and purpose her working life gave her.

It was not right the way he pushed the seamstresses. He was short so he would get up on top of the table and look down on us to see how hard we were working. One day I got a pile of blouses with the buttons uneven, they looked terrible. I told him you have

\footnotetext{
${ }^{2}$ Briki coffee is made with a small stove-top pot and tsai is the Greek word for tea.

${ }^{3}$ Eleni Veronika Costi speaks her stories using a combination of Greek and English, and a Cypriot dialect.

${ }^{4}$ For example, a seminal collaboration of visual arts responses to 'the problems and experiences of working women in Australia' in 1983-4 culminated in a book, Industrial Woman, documenting both studies, visual art and poetic responses.
} 
to stop pushing the women like that, you will lose your supplier, stop the quotas, get the quality right. But he didn't listen. He lost the main supplier.

She was prone to depression and unsuited to the life of a 'stay-at-home' mother even if that were a possible option. As a 14 year old, I recall assisting her at the Thomastown factory during my school holidays. Her pace was unrelenting and her attention to detail was uncompromised. She took minimal breaks like many of the other women. By now, she was one of the senior workers but never given a supervising role because she was a migrant woman with minimal English literacy.

\section{Kinaesthetic Grace (part 2)}

This is the woman who knows how to hold with her lined and stained hands the story of all other women we service with a system of pay-outs, women of colour on the General Motors assembly line ${ }^{5}$ playing the conveyor belt like an instrument they will never learn,

Hispanic women wearing the paper masks as they spray jeans and their lungs into shreds, and her fingers twitch when they tell of the Thomastown factory's sewing machine stitch by never-ending stitch bleeding before a stop for break the dip and throb of migraine fighting quota.

\section{Kinaesthetic inheritance}

Eleni left the factory to work alongside her husband, my father, Kostaki, in various shops selling fish and chips, fruit and vegetables, and finally landing on the one retail that took them through to retirement, selling flowers. She became a self-made florist learning the intricate wiring techniques to tame stems into a confluence of colour, bloom and scent. Again she worked tirelessly from 4 am to $6 \mathrm{pm}$, daily, to fill and refill the shop with glorious Australian buds and blossoms.

Whether it was making something out of fabric to be worn by fashionistas, or entwining eucalypt with protea, or making a suite of Cypriot dishes for a party of 60 , her hands hardly rested. They propelled her into this world of making that she inherited from her mother, my grandmother, Maroulla Elliseou.

Maroulla worked with linen and cotton to make detailed embroidery, stitch by stitch, working with white, brown and ecru thread. She started at a very young age, in her early teens, in a small village called Vasa in Cyprus. In the main room of the house, sitting on a chair with a cushion on her lap and carefully crafted multitudes of tableware, linenware, bedware, and the essentials for dowry chests. She was one of the women of Cyprus renowned for their

\footnotetext{
${ }^{5}$ Informed by the studies on intersectional systemic discrimination based on racism and sexism exemplified by the US case of the Black women factory workers taking a car manufacturer to court.
} 
Lefkarathika ${ }^{6}$ intricate embroidery skills. She was in high demand, working day and night to meet the market demand as close as Italy and as far away as America, shipped from Nicosia port. It was the Venetians who started this global trend, as during their occupation of Cyprus (1489-1571) the ruling classes holidayed in the picturesque, mountainous villages and the local women were said to have adapted the fine embroidered clothes of the Venetians into their own intricate network of stitches (Belloni 1999, p. 59).

Interestingly, Maroulla married much later than other women in her time - at the 'ripe' age of 24 years old. Her skills enabled her to rise above poverty even when her husband, my grandfather, Pappou Elliseo, journeyed to Australia seeking work, leaving her with five children, she had her embroidery to fall back on.

I remember my mother sitting and making this perfect lace. My sister and I were never as good as her. We cleaned the house, cooked the meals, took care of the chickens and goat so your Yiayia could make the money to buy us food, keep us clothed. ${ }^{7}$

\section{Impact of labour}

Both Maroulla and Eleni made the most nourishing creations, but the imprint on me was not the product. It was the impact of work on their lives. As they got older, their nimble fingers were stiffened by arthritic pain, they took heavy painkillers to continue, and their pay, working conditions and career status were overpowered by a gendered and discriminatory economic system.

The work of these women is overlooked and undervalued and they are ignored by a society which welcomes their labour but overlooks the visible realities they face trying to become active citizens in a new homeland (Duke, Lyssiotis, Mehes 1986, p. 21).

A lack of respect for traditional craft and the value of women's labour is a continuing struggle as evidenced in the wide-spread retrenchments and closures of clothing and textile factories. Not that long ago, '25 February 2009, Pacific Brands announced the closure of seven of its factories across Australia and the loss of 1850 jobs' (Textile Clothing and Footwear Union of Australia (TCFUA) 2011, p. 3). Many of these jobs were embodied by migrant women.

When we had just one job to do, it was mentally difficult. When you just see one thing day after day, after a while you could be blind and still thread cotton. You could feel if the fabric was good or not good, you didn't need to think. Your arms 'knew' the garment (anonymous worker at Bonds Factory, Unanderra, TCFUA 2011, p.16).

An undervalue of kinaesthetic skills doesn't appear to be mirrored by Ancient Greek ${ }^{8}$ deities. Ananke, a primordial deity and the personification of inevitability, compulsion and necessity, held the spindle during her reign. Spinning and weaving though was assigned to female deities, most notably Athene the Goddess of wisdom, handicraft and warfare. In reality, the life of a

\footnotetext{
${ }^{6}$ This is the Cypriot name for intricate embroidery, which became world known when in the fifteenth century Leonardo da Vinci visited Cyprus and took a Lefkara lace back to Italy with him to decorate the Duomo Cathedral in Milan.

${ }^{7}$ Words of Eleni Veronika Costi.

${ }^{8} \mathrm{~A}$ focus on Ancient Greece as distinct from other ancient civilisations given my award to study in Greece in 1995, and that both my parents are Cypriot-Greek with Greek language (although ancestral research reveals my father's Armenian ancestry).
} 
female in Classical Athens was anything but empowering. Textile production was confined to the domestic economy, which meant that 'women in the home were responsible for preparing the fleeces, for spinning thread and for weaving lengths of cloth on the loom' (Blundell 1995, p. 141). This was back-breaking work and 'better-off women had slaves who did the bulk of the work' (Blundell 1995).

The theme of these traditional skills becoming paid labour journeyed with the migration to Australia of women from the Mediterranean and the Middle-East in the early to mid-1900s. Many women, including my mother and grandmother, arrived with no or limited education and nominal English literacy. What they did possess was ingenuity with their hands and a determination to survive. Their contribution to the household income enabled the family to cross over the poverty line into the working-class (Zelda D'Aprano 1995, p. 5):

When Leon started school, mum sought employment to subsidise the family income and, because she was totally unskilled industrially, she came to an agreement with a local eiderdown manufacturer to teach her to hand-sew eiderdowns. During the first week, she plied her needle and thread without a knot and practised the skill required for her to become proficient. At the end of the week, the boss who was an acquaintance of the family, and knew our circumstances, paid her four shillings. Mum was embarrassed and refused to take it for she had not produced anything, but he insisted that she accept the money and so she had her first pay which was spent on a pair of socks for each of the children. From then on, she worked part-time in various factories and became a skilled finisher in the clothing trade. ${ }^{9}$

Well into the 1950s, Cypriot women arrived on their own to be betrothed to a photo they held onto or with their children to meet their husband after being years' apart. An unknown destiny in a foreign land fortified their skills.

Despina Pavlou has a stall where she sells children's clothes. Her husband is a linesman and they live in suburban East Burwood but his wages are not enough for them to carry out their aspirations for their six children. So Despina rises very early every day, gets the family off, has a cup of tea and sits at her sewing machine until midnight. She sells her goods at the market and makes about fifty dollars for her week's work (Larkins and Howard 1980, p. 64).

Both Despina Pavlou and my mother, Eleni, wanted a less labour intensive life for their offspring. Eleni had a habit of fanning out her palms before my face to prove the ugliness of her labour. Often there was an additional callous with its yellow hardened crust, or palm lines underscored by slashes of red, and always band aids curled around fingers to hide those cuts still weeping. This was meant to be a warning if I dared to drop out of Uni, which was constantly on my mind. Her ambition was to see me escape her plight of labour:

'I want your hands to always be this soft.'

She still reaches out for my hands, hoping they remain softer than hers. My tools are pen, paper and keyboard and so my hands are unharmed. They display no physical scars. Though Eleni is

\footnotetext{
${ }^{9}$ Zelda D'Aprono's autobiography is a detailed account of her personal and political life in order to provide a comprehensive account of working-class women's contribution to the Women's Liberation Movement in Australia. This quote from her book is about her mother who arrived from Palestine to Melbourne, in the early 1900s.
} 
not naïve, she connects my long hours staring at the screen with a system predicated on key performance indicators - the reinvention of quota targets. Her work and my work interlink at the junction of inheritance knotted with class, sex and culture.

Despite 'social distancing', her palm will continue to stroke my hand. It will continue to feel like sandpaper, and I will continue to weave her story into the threads of my poetry, which I write in the early mornings before opening the laptop to meet schedules and deadlines.

\section{Kinaesthetic Grace (part 3)}

This is the woman

silenced by statistics.

We must search for her

not in photo albums nor newspapers,

we must go out to the wild woods

where there are trees left to grow old,

like hunting for prized truffles

we must smell, touch, taste,

and when we see her

hold out our hands

as children willing to learn.

\section{Continuum of kinaesthetic skills}

Yiayia Maroulla suffered from severe dementia and died many years ago in a nursing home. Eleni is beginning to stumble with daily recall but her memory of long ago remains vivid. Their labour and aptitude hasn't transitioned in me becoming adept at turning cloth and linen into tablecloths, bedspreads and clothes. Still, I am a creation of these women, and I in turn offer an intricate sequence of threads through poetry-making. Since 1994, I have taken the threads of their stories and weaved them with mine. ${ }^{10}$

\section{Making Lace (part 1)}

I see her as I see me, sitting on chairs before the impact of our craft, both intent on making a story from a sequence, a gift out of repetition, her stitch is my letter, her design is my phrase, thread weave through out and in.

\section{Documenting the threads}

Before COVID19 infiltrated our environment, I was invited by the Greek-Australian Cultural League of Melbourne to be a featured poet as part of their Antipodean event and exhibition at Steps Gallery, Lygon Street, Carlton. This was a major occasion for not only the GreekAustralian community but other Mediterranean and Southern European communities. The 2020 theme was particularly significant as its focus of 'Connection' was a collaboration with First Nation elders and leaders.

\footnotetext{
${ }^{10}$ One of my first poems to be published in 1994 was Visiting Yiayia in Australian Multicultural Book Review.
} 
A unique intercultural dialogue promoting awareness and acceptance of cultural diversity through the sharing of art, music and storytelling, acknowledging this Land's original custodians, and the opportunities it offered to the many Greek migrants. ${ }^{11}$

Along with a plethora of arts events, it was cancelled. This event couldn't be reinvented through an online platform as a significant number of the audience comprised older generation Greeks with no computer access, limited connectivity, or a strong preference for this event to be rescheduled when it was safe to do so.

The City of Melbourne, with its COVID19 Arts Grants ${ }^{12}$, offered another way for me to present my poetry to this audience of older migrants, a similar generation to that of my mother. In April 2020, I applied for a grant to enable me to work with a filmmaker and musicians to develop a series of my poems into videopoems. These videopoems would be promoted by the GreekAustralian Cultural League via accessible online platforms and a venue when restrictions eased.

Gratefully City of Melbourne provided enough funding for a collaboration with musicians and a filmmaker with regard to four of my poems. Two of which honour and reflect on the kinaesthetic skills of Eleni and Maroulla and cover the themes unpacked in this article.

\section{Making Lace (part 2)}

she is the story on linen, no longer woman in small village sitting under a tree for days months years of thread weave through out and in, our skin an embroidery of old maps and new Lefkara, Larnaca, Kyrenia, Hartchia, Riverwood, Bankstown, Lalor, Reservoir thread weave through out and in

\section{Working with diverse women artists}

The title for the videopoems project is An Embroidery of Old Maps and New, which is a line from the Making Lace poem. This title highlights the journey of labour from grandmother to mother to daughter as a form of inheritance. The title also informed the collaborative approach to making the videopoems. Four women came together bringing their individual skills as additional layers to make the complete product. These four women include myself as the poet and narrator in the films. Sofia Chapman and Alana Hunt, who are the core of VARDOS, composed the music. VARDOS is a renowned trio of musicians playing the violin, accordion, double bass, trumpet-violin and other associated instruments to create their own adaptation of folk and Romany music. ${ }^{13}$ Sofia and Alana brought the spirit of migration, journey and tradition to the 'workshop' with their composition of music and sounds.

\footnotetext{
${ }^{11}$ Greek Cultural League Newsletter No.1/2020, March 2020.

12 These arts grants by the City of Melbourne have been offered to a wide-range of creative projects https://www.melbourne.vic.gov.au/arts-and-culture/strategies-support/funding/Pages/assistance-creatives-covid19.aspx

${ }^{13}$ Since 1993, VARDOS have been playing their music, which they learned firsthand from Roma (Gypsy) musicians during their many travels and stays in Eastern Europe. https://www.vardos.com.au/bio.htm
} 
The fourth artist to enter the workshop was Faezeh Alavi, an Iranian filmmaker and actress who in 2016 arrived in Australia to escape political and civil unrest in Iran. ${ }^{14}$ Her contribution was a combination of skill and insight; not only videography and film editor, she brought with her the insight of seeking refuge and resettlement in a foreign environment. Her selected and idiosyncratic images brought both traditional and contemporary resonance to the themes of women's labour and migration of skills.

During the collaborative period, May to June 2020, the Northern suburbs in which all four of us resided were in various stages of 'lockdown' due to the COVID19 pandemic. In early May, we were able to meet at the workshop space provided by VARDOS and map the various threads of word to music, image to sound, story to composition. Meeting my mother, Eleni, who inspired the two poems however was out of scope given her vulnerable health and selfisolation. The long phone conversations with Eleni during this period confirmed her commitment to her history and my permission to retell through my arts practice. The period of self-isolation opened Eleni's memory to witness her mother's labour and the value of sacrificial work for a 'better life' for future children.

\section{Making Lace (part 3)}

she lives in each strand of cotton perle, the white, brown and ecru, she makes houses, rivers, wells, trees, caves for secret lovers, lost children, dying soldiers, she peeks through gofti, ${ }^{15}$ through fairy windows, and sees me, letter by letter, crossing the keyboard thread weave through out and in, she sees her children's children not work in fields harvesting rotten crops, not work in factories making hard, rough, poisonous things, not work in shops selling dry, fried food, she sees a series of baby girls named after her, dressed in white, she lives in the stroke of a foreign letter by letter, word by word, thread, weave through out and in.

\section{Product of collaboration}

The first film produced was Making Lace. The VARDOS music brings to the fore a sound resonate with repetition and dedication to tradition and craft. It provides the cloth, if you like, to the voice and series of still and moving images. These images fade in and out, stitch by stitch. We begin with a closeup of a blinking eye that reveals a fish swimming through its retina, watching the woman's hands create with the traditional tools of textile craft. A younger photo of me, in my late $20 \mathrm{~s}$, which could be my mother's face, is overlayed with moving images of land signifying village life. And then the Duomo Cathedral emerges to convey the legend of how the embroidery gained global resonance. Still the hand is poking at the cathedral's turret and takes over the scene with older women's hands continuing to make.

\footnotetext{
VARDOS also have a history of collaborating with Angela Costi on various projects, including the Saloni M artist collective and events. http://www.innersense.com.au/salonim/projects/2005/index.html\#index

${ }^{14}$ Faezeh Alavi in May 2020 received her permanent residency, which confirmed her Melbourne-based practice and ability to work on the project. https://www.imdb.com/name/nm8389112/

${ }^{15} \mathrm{gofti}$ is a term used by Cypriot-Greek lace makers to refer to the holes they embroider in their intricate work.
} 
The surreal subsumes reality as we end with lace curtains fluttering in the wind - our fairy windows to brighter days.

However, producing the videopoem for Kinaesthetic Grace has proven to be challenging. Given the strong emphasis in the poem on factory life, all four of us (poet, musicians and filmmaker) were determined to find a factory site. During the period of eased restrictions we were able to have discussions with tenants, owners and workers of various factory sites. Some of these sites were abandoned, some were in use and some were new factory sites. The issues with accessing these sites for filming were not concerned with risks associated with spread of the virus, rather they feared public liability and potential damage to reputation. One factory owner alluded to the poem being too political. At the time of writing, we still haven't successfully located a site for filming, and now the restrictions in the North of Melbourne where we live and where the poem locates the factory, are severe as community transmission has peaked.

This hasn't stopped the research and access to images that signify the essence of the poem. We have viewed the series of photo stills of women's hands sewing garments at the Bonds, Unanderra, NSW factory, just before it closed in March 2010 (TCFUA 2011, Bailey 2011). These series of photos are filmic in themselves as they capture second by second the work required to sew a garment together. They distil both experience and skill required to avoid the drill of the needle drawing blood, to create the seamless feel of an iconic Bonds t-shirt.

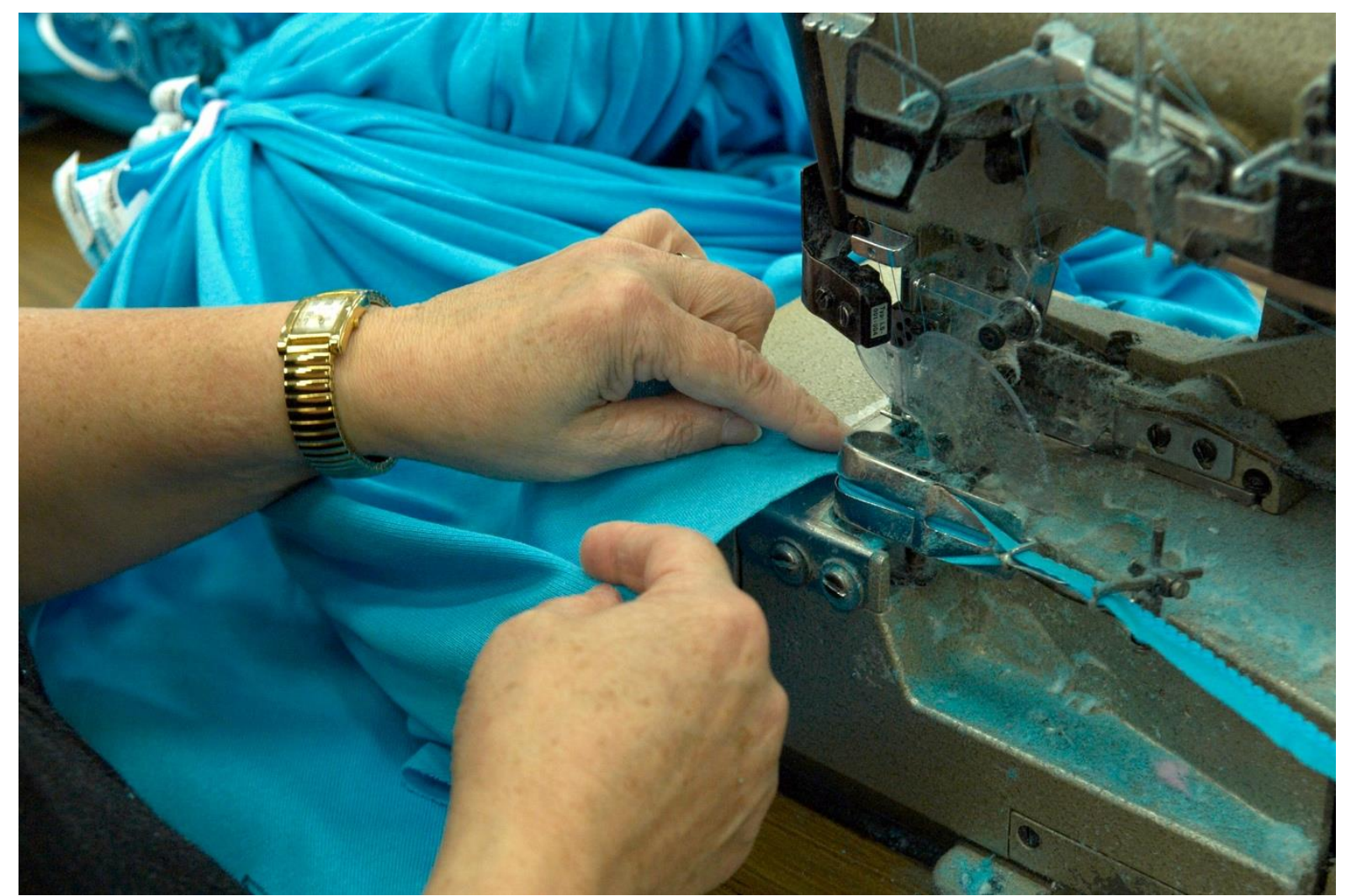

Garment worker's hands, Bonds factory, NSW. Photograph by Angela Bailey. 


\section{Conclusion}

Spinning, weaving and sewing associated with the skills of Ancient Greek women continues throughout centuries to embody women's work. This continuum of pride connected to the ability to produce desirable product is cast with pain incurred through the relentless repetition and long hours. Community-engaged projects such as Work on the line demonstrates through artistic collaboration the significance of migrant women's work to the history of Australian textile manufacture.

Furthermore, creatively documenting the personal narratives of migrant women's skills and work contributes to our contemporary study of women's significant contribution to global industrialised labour. Both autobiographical (Zelda D'Aprano 1995) and biographical (Eleni's oral memories) provide the detail of observation and reflection inspiring a communityengaged, collaborative arts project. Older Greek migrants (as well as others from the Mediterranean, Middle-East and Europe) are keen to view stories that resonate with their experience and reflect their contribution to Australian history. Through the arts project, $A n$ Embroidery of Old Maps and New, a poet, two musicians and a filmmaker informed by their own cultural heritage, study and travels, endeavour to make videopoems that add to the knowledge of women's work with hands.

\section{Author Bio}

Angela Costi studied Law/Arts at Melbourne University enabling her to practice as a lawyer and she is currently a public servant within the social justice sector. In her mid-20s she left legal practice and resumed studies. She completed the Professional Writing and Editing course at RMIT. She also received a travel award from the National Languages Literacy Board in 1993, which enabled her to study Ancient Greek drama in Greece. From 1995, she has also freelanced as a community writer working within a community-engaged framework to create collaborative art with diverse groups or collectives. She was the writer and co-creator of the Relocated arts project, which was commissioned by the City of Melbourne and received the national award for Innovation and Excellence in community services 2002. She is the author of four poetry collections and her writing has been published in journals, including Hecate, Southerly, Meanjin and Overland.

\section{Acknowledgment}

I'm grateful to Helena Spyrou for her guidance as she was employed by the TCFUA to produce the arts-based project Work on the line, and a series of nationwide projects involving the retrenchment of women working within the clothing and textile industry of Australia. Also, thank you to Angela Bailey who provided permission to use her photo.

\section{Bibliography}

Belloni, S. (1999). Cyprus. Plurigraf, Narni.

Blundell, S. (1995). Women in Ancient Greece. British Museum Press.

Chen, M. (2013, March). Your "distressed" jeans are wearing out workers' lungs. Huffington Post. https://www.huffpost.com/entry/your-distressed-jeans-are_b_3642180

Costi, A. (2020). Kinaesthetic Grace. StylusLit. 7. 
https://styluslit.com/poetry/kinaesthetic-grace/

---. $\quad$ (2011). Making Lace. In N.N.Trakakis (Ed.) Southern sun, Aegean light - Poetry of second-generation Greek-Australians, (pp. 66-67), Arcadia.

---. $\quad$ (1994). Visiting Yiayia. Australian Multicultural Book Review. 2 (3), 23.

Crenshaw, K., Peller, G., Thomas, K., Gotanda, N. (Eds.) (1996). Critical race theory: The key writings that formed the movement. The New Press.

D’Aprano, Z. (1995). Zelda. Spinifex.

Duke, J., Lyssiotis, P., Mehes V. (1986). Industrial woman. Industrial Woman Collective.

Justia US Law, 4 May (1976). DeGraffenreid v General Motors Assembly Div., United States District Court for the Eastern District of Missouri, 413 F. Supp. 142 https://law.justia.com/cases/federal/district-courts/FSupp/413/142/1660699/

Larkins, J., Howard, B. (1980). A tribute to Australian women. Rigby.

Lillie, J., Larsen, K., Kirkwood, C., Brown, JJ. (Eds.) (2020). The relationship is the projectworking with communities, Brow Books.

Textile Clothing and Footwear Union of Australia (TCFUA) (2011). Work on the line, TCFUA. 